Article

\title{
Seed Burial Depth and Soil Water Content Affect Seedling Emergence and Growth of Ulmus pumila var. sabulosa in the Horqin Sandy Land
}

\author{
Jiao Tang ${ }^{1,2}$, Carlos A. Busso ${ }^{3}$, Deming Jiang ${ }^{1, *}$, Yongcui Wang ${ }^{1}$, Dafu Wu ${ }^{4}$, Ala Musa ${ }^{1}$, \\ Renhui Miao ${ }^{1,2}$ and Chunping Miao ${ }^{1,2}$ \\ Received: 23 October 2015; Accepted: 7 January 2016; Published: 13 January 2016 \\ Academic Editor: Giovanni de Feo \\ 1 Institute of Applied Ecology, Chinese Academy of Sciences, Shenyang 110016, China; \\ tangjiaoviva1988@126.com (J.T.); yongcuiwang@iae.ac.cn (Y.W.); alamusa@iae.ac.cn (A.M.); \\ miaorenhui@henu.edu.cn (R.M.); miaochunping316@163.com (C.M.) \\ 2 University of Chinese Academy of Sciences, Beijing100048, China \\ 3 Departamento de Agronomía-CERZOS (CONICET), Universidad Nacional del Sur, San Andrés 800, \\ Bahía Blanca 8000, Argentina; cebusso@criba.edu.ar \\ 4 Department of Resource and Environment, Henan Institute of Sciences and Technology, Xinxiang 450003, \\ China; uau@hist.edu.cn \\ * Correspondence: jiangdeming@iae.ac.cn; Tel.: +86-24-8397-0339
}

\begin{abstract}
We investigated the effects of seed burial depth and soil water content on seedling emergence and growth of Ulmus pumila var. sabulosa (sandy elm), an important native tree species distributed over the European-Asian steppe. Experimental sand burial depths in the soil were 0.5, 1.0, $1.5,2.0$ and $2.5 \mathrm{~cm}$, and soil water contents were $4 \%, 8 \%, 12 \%$ and $16 \%$ of field capacity. All two-way ANOVA (five sand burial depths and four soil water contents) results showed that seed burial depths, soil water content and their interactions significantly affected all the studied plant variables. Most of the times, seedling emergence conditions were greater at the lower sand burial depths (less than $1.0 \mathrm{~cm}$ ) than at the higher (more than $1.0 \mathrm{~cm}$ ) seed burial depths, and at the lower water content (less than 12\%) than at the higher soil water content. However, high seed burial depths (more than $1.5 \mathrm{~cm}$ ) or low soil water content (less than $12 \%$ ) reduced seedling growth or change in the root/shoot biomass ratios. In conclusion, the most suitable range of sand burial was from 0.5 to $1.0 \mathrm{~cm}$ soil depth and soil water content was about $12 \%$, respectively, for the processes of seedling emergence and growth. These findings indicate that seeds of the sandy elm should be kept at rather shallow soil depths, and water should be added up to $12 \%$ of soil capacity when conducting elm planting and management. Our findings could help to create a more appropriate sandy elm cultivation and understand sparse elm woodland recruitment failures in arid and semi-arid regions.
\end{abstract}

Keywords: seed burial depth; sandy elm; seed germination; seedling emergence; soil water content

\section{Introduction}

Seed production and dispersal, the dynamics of soil seed bank, and seed germination and establishment are important processes contributing to the regeneration of natural vegetation [1]. Seed germination and seedling establishment are the most sensitive processes (e.g., water stress [2]) among these plant life history traits [3]. Su et al. [4] also reported that water stress is a major obstacle for a successful vegetation establishment in arid and semi-arid regions. Other abiotic stresses such as temperature, light and low nutrient contents are also dominant aspects altering the fate of seeds $[5,6]$. Furthermore, the characteristics of seeds (e.g., seed mass, seed shape and seed dormancy) also regulate 
seed density $[7,8]$. Therefore, decisive factors impacting vegetation restoration in arid regions are successful seed germination and the subsequent establishment and development of seedlings $[9,10]$.

Sparse elm woodland is widely distributed over the European-Asian steppe, and it has become the original landscape in Horqin Sandy Land, Otindag Sandy Land of China [11]. The landscape is characterized by either single or (more often) groups of trees, and well-developed grass-shrub vegetation [12]. Ulmus pumila var. sabulosa (sandy elm) is the main tree species in this area. It is closely related to human life, providing hardwood for farming tools and fuel, and tender leaves and edible bark for feeding [13]. However, the number of remnant mature elms has reduced sharply, and few saplings have appeared in the last decades because of environmental deterioration. Almost no sandy elm seedlings established even though seed dispersal has been abundant in this area; this has modified the plant age structure, and led to degradation of woodland ecosystems [14].

Sandy lands are often exposed to numerous environmental stresses such as frequent winds and low precipitation $[15,16]$. They are characterized by sparse vegetation and loose soil texture; because of frequent sand movement, plants are often buried by sand compared with other areas [17]. Nevertheless, this is important for seed germination, seedling emergence and establishment since a certain degree of sand burial is needed at the early developmental morphology stages if plants are to grow and establish properly [10].

Most research on the sandy elm has focused on its physiological characteristics and adaptive strategies due to the limited sparse elm woodland area [18-20]. Research on the effects of sand burial and water content on the seedling emergence and growth of Ulmus pumila var. sabulosa is currently scarce. The objectives of this study were to determine the influence of various levels of sand burial and soil water content on the seedling emergence and growth of sandy elm.

\section{Materials and Methods}

\subsection{Experimental Materials}

Mature intact and plump seeds of sandy elm were collected during mid-May 2015 in Horqin Sandy Land, China. Soil was obtained at the study area in Horqin Sandy Land, and heated to $105^{\circ} \mathrm{C}$ during $48 \mathrm{~h}$ to kill seeds in it. Several studies on seedling growth and development have been conducted using soil which was treated in autoclave [21,22]. In this case, microbial populations are reduced, but not eliminated (Cabezali, Agronomy Department, National University of the south, Argentina). Also, arrival of new microorganism to the treated soil (e.g., spores of arbuscular mycorrhizae) could be by air [23]. Thereafter, transparent plastic pots $(0.30 \mathrm{~m}$ height, $0.25 \mathrm{~m}$ diameter $)$ with uniform needle holes at the bottom were selected. Holes were covered with nylon mesh to prevent soil loss while allowing drainage of water at the same time. Irrigation water came from local groundwater.

\subsection{Experimental Procedures}

We used a completely randomized experimental design with five replicates. A factorial study (five sand burial depths $\times$ four soil water contents) consisting of 20 treatments was conducted. Within each replicate, 36 seeds in each pot were first placed at $0.5,1.0,1.5,2.0$ or $2.5 \mathrm{~cm}$ soil depth, and thereafter buried by adding the experimental soil. The total number of seeds monitored since the beginning of the experiment was 3600 (36 seeds/replicate $\times$ five replicates/treatment $\times 20$ treatments). At each depth, seeds were evenly spaced on the soil surface. Field capacity was determined gravimetrically by measuring soil water content after two days of saturating the soil $[24,25]$. Soil water contents were $4 \%$, $8 \%, 12 \%$ or $16 \%$ of soil field capacity via manual irrigation. Irrigation amounts were determined as the pot weight difference between the maximum weight at field capacity and that needed to reach each of the study soil water contents. Water lost by evapotranspiration was replaced daily by reweighing each pot during the experimental period. Four percentage and $8 \%$ are the minimum water required for seed germination and the local average soil water content during the growing season, respectively. Plastic pots were placed into a climate incubator (MGC-350HPY-2, Panasonic, Japan). Following local 
meteorological records, seeds were exposed to a $16 \mathrm{~h}$ photoperiod at $25^{\circ} \mathrm{C}$, and to an $8 \mathrm{~h}$ darkness at $18{ }^{\circ} \mathrm{C}$. Air humidity was set to $45 \%$. Illumination intensity was set in 11,000 Lux.

Emerged seedlings with visible cotyledons were counted. Duration of the study was 30 days from late May to late June in 2014. At the end of the study, soil within the pots was passed through a screen mesh; germinated seeds which did not produce seedlings were first retained in that mesh and thereafter counted. At this time, eight seedlings were randomly selected per treatment. Roots and shoots of these seedlings were dried at $80^{\circ} \mathrm{C}$ during $24 \mathrm{~h}$ and weighed. Thereafter, root/shoot ratios were calculated.

Before the experiment, seed germination was tested using petri dishes in the same climate incubator. Water was added to filter papers (seeds had been spread on) as to keep them fully wet every day, and numbers of germinated seeds were counted until achieving a stable, maximum germination percentage. Seeds were considered germinated after radicle emergence. Maximum germination percentage of seeds was $85.2 \% \pm 4.9 \%$.

\subsection{Determination of Seed Germination and Seedling Emergence}

The percentage of seedling emergence was determined as the number of seeds that emerged to the soil surface/the total number of tested seeds $\times 100 \%$. The percentage of germinated seeds which did not produce seedlings was obtained as the number of germinated seeds that were retained in the mesh/the total number of tested seeds $\times 100 \%$. Meanwhile, the rate of seedling emergence (GI) was calculated using the formula:

$$
\mathrm{GI}=\sum \frac{100 G i}{n T i}
$$

where $G i$ is the number of seeds that germinated and emerged on day $T i(T i=1,2,3 \ldots)$, and $n$ is the total number of tested seeds in every treatment [26]. Seedling height and the root-to-shoot ratio of seedlings were determined as a measure of growth and biomass allocation, respectively.

\subsection{Statistical Analysis}

Before the analysis was done, the percentage data were normal distribution and homogeneity using square root arcsine transformation, but untransformed data are shown in the table and figures $[27,28]$. One-way or two-way analysis of variances (ANOVAs) at the $95 \%$ probability level were conducted to compare treatment effects [27]. If ANOVA showed significant effects, Tukey's test was used to determine differences between treatments. All statistical analyses and drawings were made using Origin Pro 9.0 (OriginLab Corp, Northampton, MA, USA). There was no seedling emergence when seeding was made at $2.5 \mathrm{~cm}$ soil depth. Because of this, only the percentage of germinated seeds was used in the analysis of variance at this depth in response to sand burial and soil water content.

\section{Results}

\subsection{Seedling Emergence and Speed of Seedling Emergence}

Two-way ANOVA analyses showed that depths of sand burial, soil water content and their interactions had a significant effect on the final percentage of emerged seedlings and the rate of seedling emergence $(p<0.001$, Table 1$)$. Greatest $(52.4 \%)$ and lowest $(22.0 \%)$ values of seedling emergence were found at 0.5 and 1.5 and $2.0 \mathrm{~cm}$ soil depths, respectively, in the same soil water content (Figure 1A). Seedling emergence percentage was more than $12.9 \%$ greater $(p<0.05)$ at 0.5 than at $1.0 \mathrm{~cm}$ of seed burial depths in each of the soil water contents (Figure 1A). When in the same burial depths, this value increased as soil water content increased from $4 \%$ to $12 \%$ at 0.5 and $1.0 \mathrm{~cm}$, but not at 1.5 and $2.0 \mathrm{~cm}$ soil depths (Figure 1B). At these later sand burial depths, however, seedlings were similar among all experimental soil water contents (Figure 1B). The percentage of seedling emergence was also similar at $8 \%$ and $16 \%$ of soil water contents at 0.5 and $1.0 \mathrm{~cm}$ depths of sand burial (Figure 1B). 
Table 1. Two-way ANOVAs for the effects of soil water content and depth of seed burial on seedling emergence percentage and the rate of seedling emergence of Ulmus pumila var. sabolusa.

\begin{tabular}{cccccc}
\hline \multirow{2}{*}{ Source of Variation } & \multirow{2}{*}{ DF } & \multicolumn{2}{c}{ Seedling Emergence Percentage (\%) } & \multicolumn{2}{c}{ Rate of Seedling Emergence (Day ${ }^{-1}$ ) } \\
\cline { 3 - 6 } & & $\boldsymbol{F}$-Value & $\boldsymbol{p}$-Value & $\boldsymbol{F}$-Value & $\boldsymbol{p}$-Value \\
\hline Depth of seed burial & 3 & 137.470 & 0 & 201.103 & 0 \\
Soil water content & 3 & 26.371 & $<0.001$ & 13.645 & $<0.001$ \\
Interaction & 9 & 6.276 & $<0.001$ & 4.459 & 0 \\
\hline
\end{tabular}

At all soil water contents, the rate of seedling emergence decreased at least $81 \%$ as the depth of sand burial increased from 0.5 to $2.0 \mathrm{~cm}$ (Figure 1C). The rate of seedling emergence was more than $47 \%$ greater at 1.5 than $2.0 \mathrm{~cm}$ of sand burial at all soil water contents (Figure 1C). When seeds were buried in sand at $0.5 \mathrm{~cm}$ and $1.0 \mathrm{~cm}$ depths, the rate of seedling emergence significantly increased more than $62 \%$ from $4 \%$ to $12 \%$ of soil water content. However, the values were similar $\left(8.1\right.$ day $\left.^{-1}\right)$ at $8 \%$ and $16 \%$ of soil water content (Figure 1D). Also, the seedling emergence rate showed a similar trend among different soil water content at $1.5 \mathrm{~cm}\left(3.4\right.$ day $\left.^{-1}\right)$ and $2.0 \mathrm{~cm}\left(1.8\right.$ day $\left.^{-1}\right)$ of sand burial depths (Figure 1D).
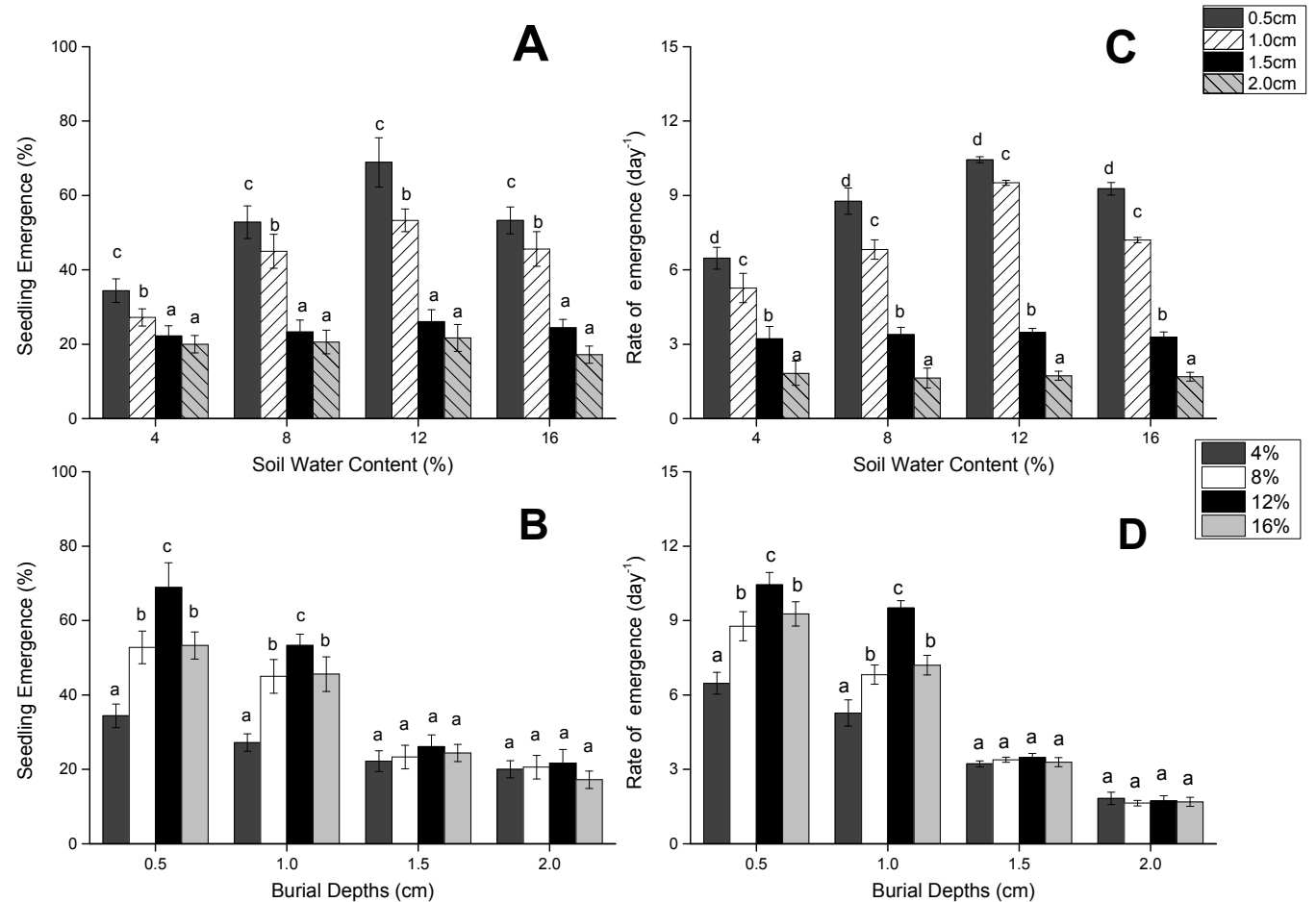

Figure 1. Seedling emergence and rate of seedling emergence for seeds of Ulmus pumila var. sabulosa buried by sand to various depths and exposed to various soil water contents. (A) Seedling emergence exposed to different soil water contents; (B) Seedling emergence buried by different sand burial depths; (C) Rate of emergence exposed to different soil water content; (D) Rate of emergence buried by different sand burial depths. Each histogram is the mean \pm 1 S.E. of $n=5$. Within each soil water content or burial depth, different letters among themindicate significantly differences at $p<0.05$.

\subsection{Germinated Seeds Which Did Not Grown into Seedlings}

The percentage of germinated seeds that had not grown into seedlings was affected by the depths of sand burial and soil water content and their interactions $(p<0.001$, Table 2$)$. Seed germination was more than $49.5 \%$ greater at $2.5 \mathrm{~cm}$ than at 1.0 and $1.5 \mathrm{~cm}$ of sand burial depths when soil water contents 
were in the range of $4 \%$ and $8 \%$ (Figure $2 \mathrm{~A}$ ). At $12 \%$ and $16 \%$ of soil water contents, however, the value was lower at 1.0 and $2.5 \mathrm{~cm}(3.3 \%)$ than at the other three (8.1\%) sand burial depths (Figure 2A). At all studied sand burial depths, the seed germination percentage was similar at $4 \%$ and $8 \%$ of soil water content (Figure 2B). This value was at least $28.3 \%$ greater at $4 \%$ and $8 \%$ than at $12 \%$ and $16 \%$ of soil water contents at sand burial equal to or greater than $1 \mathrm{~cm}$. However, seed germination was $25 \%$ greater at $12 \%$ than $16 \%$ of soil water content at $0.5 \mathrm{~cm}$ sand burial depths (Figure 2B).

Table 2. Two-way ANOVAs for the effects of soil water content and depth of sand burial on germinated seeds that had not grown into seedlings of Ulmus pumila var. sabolusa.

\begin{tabular}{ccccc}
\hline \multirow{2}{*}{ Source of Variation } & \multicolumn{4}{c}{ Germinated Seeds Which Did Not Grow into Seedlings (\%) } \\
\cline { 2 - 5 } & DF & Mean Square & F-Value & $p$-Value \\
\hline Depth of seed burial & 4 & 65.922 & 6.631 & $<0.001$ \\
Soil water content & 3 & 1403.936 & 141.219 & 0 \\
Interaction & 12 & 45.198 & 4.546 & $<0.001$ \\
\hline
\end{tabular}

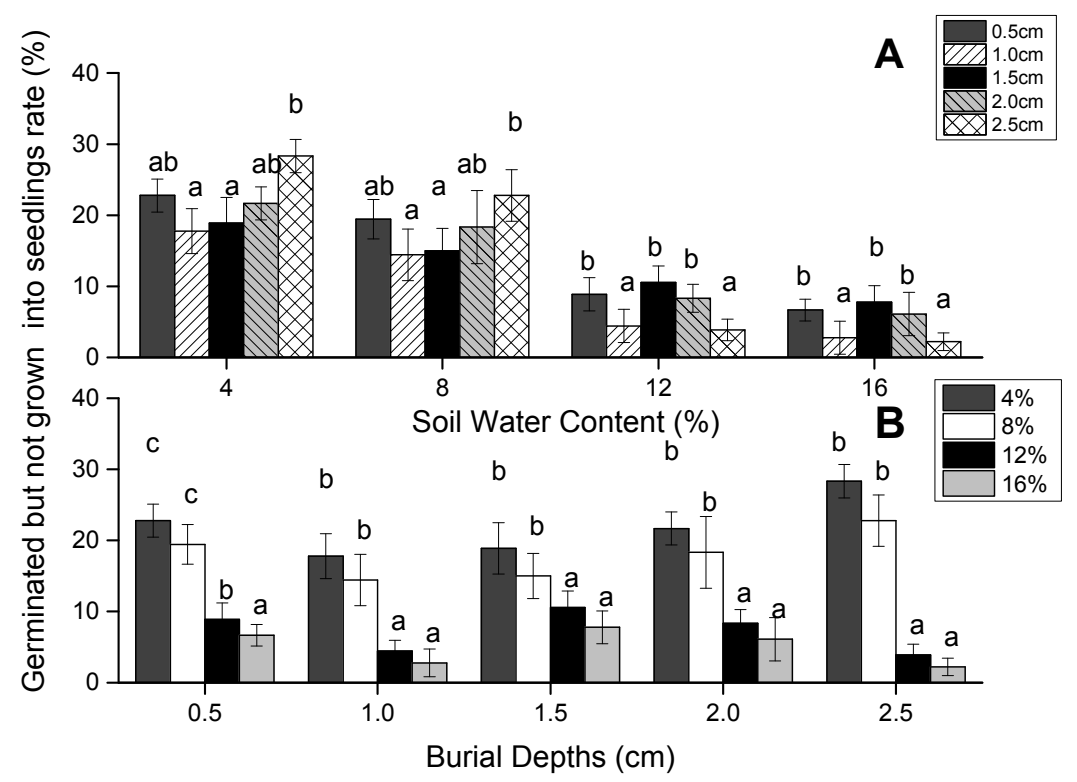

Figure 2. Germinated seeds which didnot grow into seedlings (\%) on Ulmus pumila var. sabolusa buried by sand to various depths and soil water contents. (A) Germination but not grown into seedling rate exposed to different soil water content; (B) Germination but not grown into seedling rate buried by different sand burial depths. Each histogram is the mean \pm 1 S.E. of $n=5$. Within each soil water content or burial depth, different letters among them indicate significantly differences at $p<0.05$.

\subsection{Seedling Height and Root/Shoot Ratio}

There were significant effects of burial treatments, soil water content and their interactions on seedling height and the root/shoot ratio $(p<0.05$, Table 3$)$. Seedling height was similar when seeds were buried between 0.5 and $1.5 \mathrm{~m}$ depths of sand at $4 \%, 12 \%$ and $16 \%$ soil water content (Figure $3 \mathrm{~A}$ ). At all soil water contents, seedling height was greater at $0.5,1.0$ and $1.5 \mathrm{~cm}$ than at $2.0 \mathrm{~cm}$ of sand burial depths (Figure 3A). At $8 \%$ of soil water content, seedling height was similar at 0.5 and $1.5 \mathrm{~cm}$ burial depths, and greater at $1.0 \mathrm{~cm}$ than $2.0 \mathrm{~cm}$ depth of sand burial (Figure 3A). On all studied sand burial depths, seedling heights were greatest at $12 \%$ and $16 \%$, and lowest at $4 \%$ of soil water contents (Figure 3B). 
Table 3. Two-way ANOVAs for the effects of soil water content and depth of sand burial on seedling height and root/shoot ratio of Ulmus pumila var. sabulosa.

\begin{tabular}{cccccc}
\hline \multirow{2}{*}{ Source of Variation } & \multirow{2}{*}{ DF } & \multicolumn{2}{c}{ Seedling Height } & \multicolumn{2}{c}{ Root/Shoot Ratio } \\
\cline { 3 - 6 } & & $\boldsymbol{F}$-Value & $\boldsymbol{p}$-Value & $\boldsymbol{F}$-Value & $\boldsymbol{p}$-Value \\
\hline Depth of seed burial & 3 & 50.344 & 0 & 20.271 & $<0.001$ \\
Soil water content & 3 & 279.845 & 0 & 42.422 & 0 \\
Interaction & 9 & 2.243 & 0.024 & 4.124 & 0.04 \\
\hline
\end{tabular}

Root/shoot biomass ratio firstly decreased and then increased as the sand burial depths increased in the same soil water content (Figure 3C). At $4 \%$ of soil water content, the ratio was similar (about 0.3 ) among seed burial depths (Figure 3C). However, the root/shoot ratio was significantly greater at 2.0 than $1.0 \mathrm{~cm}$ burial depths when soil water contents were from $8 \%$ to $16 \%$, except no difference was found at 0.5 and $1.5 \mathrm{~cm}$ of sand burial depths (Figure 3C). At $12 \%$ and $16 \%$ of soil water contents, the root/shoot biomass ratio was significantly lower at $1.0 \mathrm{~cm}$ than at other depths of sand burial (Figure 3C). When in the same sand burial depth, the greatest and lowest root/shoot ratios were found at $4 \%$ and $16 \%$ of soil water contents (Figure $3 \mathrm{D}$ ).

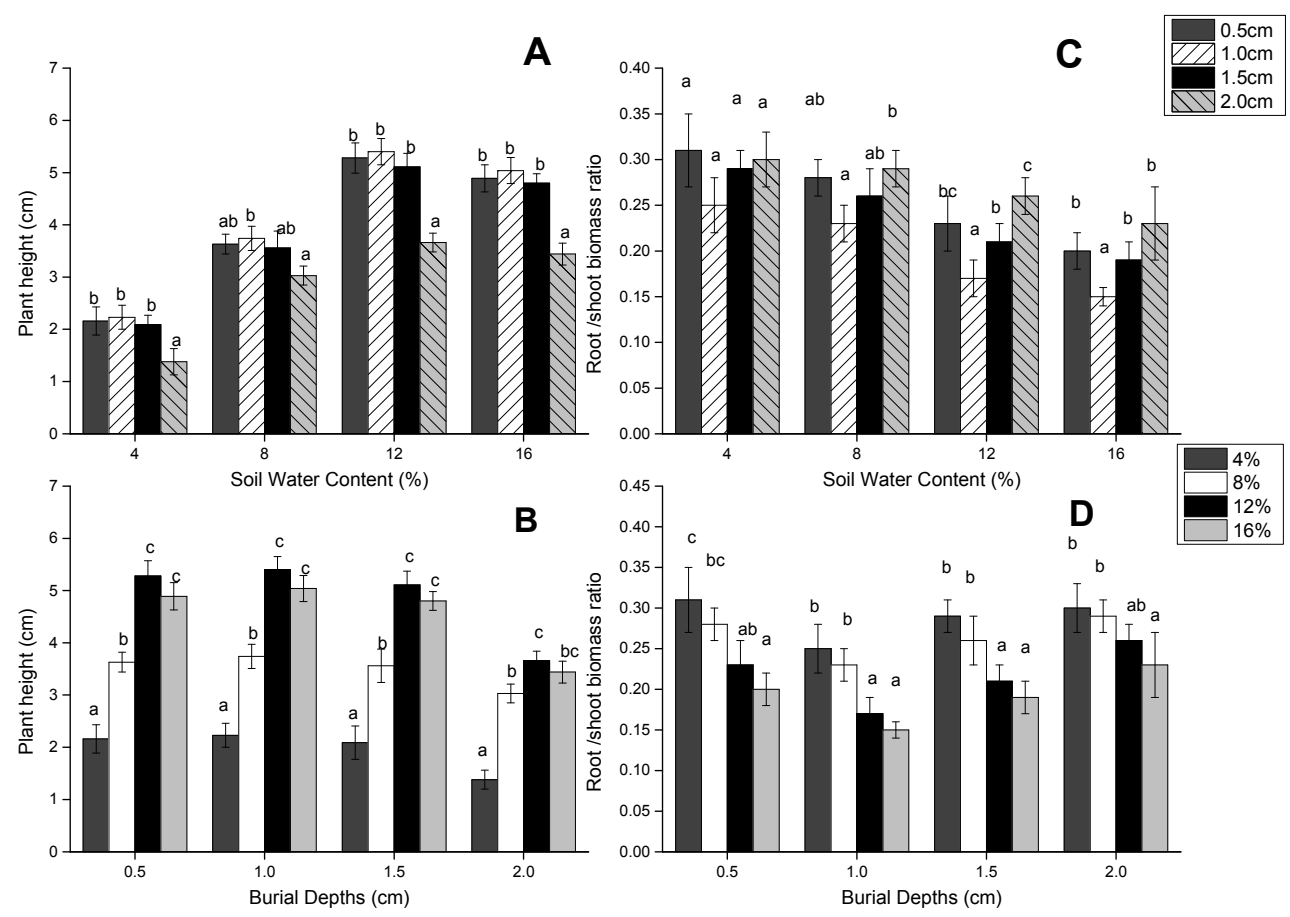

Figure 3. Seedling height and root/shoot ratio of Ulmus pumila var. sabolusa after burying seeds insand at various depths and exposing them to different soil water contents. (A) Seedling height exposed to different soil water content; (B) Seedling height buried by different sand burial depths;.(C) Root/shoot ratio exposed to different soil water content; (D) Root/shoot ratio buried by different sand burial depths. Each histogram is the mean \pm 1 S.E. of $n=5$. Within each soil water content or burial depth, different letters among themindicate significantly differences at $p<0.05$.

\section{Discussion}

\subsection{Seed Germination, Seedling Emergence and Speed of Seedling Emergence}

In the sand land regions, seeds are exposed to various degrees of sand burial after dispersal [10]. Sand burial can substantially modify various soil physical variables for vegetation establishment 
and growth; these variables could reduce temperature, enhance humidity and improve soil microenvironment characteristics, becoming a critical factor for regulating plant distribution and community establishment [17]. Seedling emergence and growth are exposed to a certain degree of sand burial at early developmental morphology stages, which could modify plant establishment and allow colonization of new habitats in the sandy environments [7,9].

Timing of dispersal of elm seeds coincides with the period of frequent sand blown by winds; as a result, most seeds are exposed to various degrees of sand burial [20]. Results of our study showed that the optimal seed burial depth by sand was 0.5 to $1.0 \mathrm{~cm}$ for seed germination, which subsequently determined the final emergence percentage and rate of seedling emergence. There was a marked reduction in the percentage and rate of seedling emergence when seed burial by sand exceeded $1.0 \mathrm{~cm}$. No seedlings emerged were found when seeds were buried by more than $2.0 \mathrm{~cm}$. These results suggest that $1.0 \mathrm{~cm}$ of seed burial is a crucial threshold for seed germination, and beyond this sand burial depth, these variables most likely will be markedly reduced. This confirms previous findings on the perennial sand-dune grass Leymussecalinus in the Mu-Us sandy land [28] and on the psammophyte species Hedysarun leave and Caraganakorshinskii in the Ordos plateau [29]. The reported sand burial depth for a suitable germination and seedling emergence of most woody plants has been approximately $2.0 \mathrm{~cm}$; when sand burial has been greater than that, the processes of seed germination and seedling emergence would be reduced [30]. Reductions in seedling emergence might not only be related to sand burial depths, but also with energy storage in seeds and seed morphological structures [2]. A greater energy storage in the endosperm or cotyledons of seeds increase the probability that seedlings can emerge from deeper soil depths [31]. Increases of seed burial by sand increases soil compaction, which subsequently increases the resistance to growth from apical meristems, thus preventing stems from growing up. Meanwhile, the shape of seeds can also affect seedling emergence [13,32]. Slender and oval seeds have shown a trend to germinate and emerge rapidly in the soil [7]. Compared with other woody plants, sandy elm seeds have a relatively low quality, having limited nutrients but a wing structure that can absorb water easily. This can increase the contact with sandy soil but reduce the probability of germination from the soil surface $[12,19]$. Sandy elm seeds have not shown dormancy characteristics, and their survival period after dispersal has been low [14]. Large numbers of seeds can be found dead in the deep soil profile, which contributes to explaining the low seedling emergence after seed dispersal in the Horqin Sandy Land.

Soil moisture is also an important factor for determining seed germination and seedling emergence [28]. Water uptake by seeds would be greatly reduced if soil moisture is low [13]. Even though seeds can germinate when enough soil water is available, soil moisture conditions might not be subsequently enough to maintain seedling emergence [33]. Within a certain range of soil water contents, however, the capacity for seedling emergence can be enhanced if soil water contents are increased. We demonstrated that at $12 \%$ of soil water content, seeds showed the greatest germination percentage and rate of seedling emergence, and a low percentage of germinated seeds that had not grown into seedlings. These results are in agreement with the response of Artemisiaordosica and Artemisia. sphaerocephala to soil moisture in western China [34,35]. When soil water content was over $12 \%$, seedling emergence and the rate of seedling emergence declined. This may be the result of a high soil water content reducing soil aeration and oxygen availability in the soil [36]. In the wild area, when humidity was too high, the number of soil microbial pathogens was increased and that of symbiotic fungi was reduced, which was not conducive to seedling emergence and growth [37]. In a previous exploratory study in the study area, we found out that the average soil surface water content was from $1 \%$ to $4 \%$, and it reached $5 \%-7 \%$ after moderate rains. These conditions might be conducive to low seed germination. Simultaneously, strong winds and high evaporation often occur during the period of seed dispersal at our study site. This might further reduce seed germination and subsequent seedling emergence because of an insufficient water supply. This might help to explain the lower percentage of seedling emergence and the rate of seedling emergence, but not excessive (i.e., 16\%) soil water contents from 0.5 and $1.0 \mathrm{~cm}$ of sand burial depths in our study. Also, soil water contents equal to or greater 
than $12 \%$ significantly decreased the percentage of germinated seeds which grew up into seedlings in comparison to lower soil water contents.

\subsection{Seedling Height and Root/Shoot Ratio}

Height and root/shoot ratio are important indicators of seedling growth and biomass allocation, respectively. Seedling growth is vulnerable to external environmental factors at early developmental morphology stages [16]. Within $4 \%$ to $12 \%$ soil water contents, seedling height increased independently of the study seed burial depths. These results are in agreement with reports on Artemisia ordosica and Artermisia monosperma [34,38]. However, Seiwa et al. [31] reported that seedling growth was inhibited because of excessive soil water contents and poor soil aeration. This might contribute to explaining the lower seedling height at $16 \%$ than at $12 \%$ of soil water content at all studied seed burial depths. Seedling height was greatest at the $0.5 \mathrm{~cm}$ seed burial depth when the soil water content was $12 \%$. However, when the soil water contents was from $8 \%$ to $16 \%$, seedling height was greater at 0.5 and $1.0 \mathrm{~cm}$ of sand burial depths than at 1.5 and $2.0 \mathrm{~cm}$ seed burial depths. A similar growth stimulation at lower seed burial depths was reported on Suaeda salsa and Triplasispurpurea [39,40]. Sun et al. [40] showed that moisture could be kept in the root zone at smaller rather than greater seed burial depths to improve seedling growth and development. These positive feedback effects would recede when plant tolerance levels are exceeded, thus constraining the subsequent plant growth [39].

Plants shifted biomass allocation in response to decreases in soil water content: under these conditions, there was a greater biomass allocation to roots than shoots. Liu et al. [17] reported that changes in biomass allocation are meant to reduce the influence of external disturbances and guarantee normal growth and development. Increases of soil water content, on the other hand, increased biomass allocation to shoots which will most likely lead to increases in photosynthesis [40]. Under any study of soil water content, moderate seed burial depth $(i . e ., 1 \mathrm{~cm})$ increased biomass allocation to above-ground tissues. Similar effects have been reported for Psammochloavillosa [37] and Achnatheruninebrians [41]. These authors showed that there was a positive relationship between the depth of seed burial and the fixation of light energy, which in turn induced a greater biomass allocation to roots during the early developmental morphology stages of seedlings [41]. However, few plants buried in sand have been able to transfer $C$ resources from roots to shoots (e.g., Caraganaintermedia: [32]; Bromusinermis: [42]). These findings show that plant biomass allocation in response to sand burial not only depends on the species but it is also associated with the plant adaptation to the habitat.

\section{Conclusions}

Soil water content, seed burial depth and their interactions had a significant effect on the proportion of germinated seeds which did not grow out into seedlings, and on seed germination and seedling emergence, and the growth and development of the sandy elm. Either low or excessive soil water content or seed burial depth would reduce the ability for seedling emergence and growth of the sandy elm. The most suitable range of seed burial depth was from 0.5 to $1.0 \mathrm{~cm}$ and the soil water content was about $12 \%$, respectively, for the processes of seedling emergence and growth at the early developmental morphology stages of seedlings. The different responses of the studied plant variables to soil water content and seed burial depth indicate that the burial of seeds by sand should be rather shallow from the soil surface (i.e., $0.5 \mathrm{~cm}$ to $1.0 \mathrm{~cm}$ ) and watering should be done during the dry season in artificial cultivation.

Acknowledgments: This study was supported by National Natural Science Foundation of China (31370706). We thank Xiaoyu Wang and Yongming Luo for help during the experiment. Thanks Guangyou Hao, Yajuan Zhu, Zhimin Liu and Xinhai Li for guiding of statistical analysis in the experiment and two reviewers whose comments greatly improved the contents of this manuscript.

Author Contributions: Jiao Tang conducted this experiment and wrote the manuscript; Carlos A Busso revised and rewrote a large part of this manuscript; Dafu Wu and Alamusa revised the manuscript. Deming Jiang and Yongcui Wang designed this experiment. Renhui Miao and Chunping Miao were responsible for data analysis. 
Conflicts of Interest: The authors declare no conflict of interest.

\section{References}

1. Peng, S.; Huang, Z.Y.; Peng, S.L.; Ou Yang, X.; Xu, G. Factors influencing mortality of seed and seedling in plant nature regeneration process. Guihaia 2004, 24, 113-124.

2. Zheng, M.Q.; Zheng, Y.R.; Jiang, L.H. Effects of one-time water supply and sand burial on seed germination and seedling emergence of four populary psammophyte in Mu Us sandy land. Acta Ecol. Sin. 2006, 26, 2474-2484.

3. Du, X.F.; Guo, Q.F.; Gao, X.M.; Ma, K.P. Seed rain, soil seed bank, seed loss and regeneration of Castanopsis fargesii (Fagaceae) in a subtropical evergreen broad-leaved forest. For. Ecol. Manag. 2007, 238, 212-219. [CrossRef]

4. Su, H.; Li, Y.G.; Liu, W.; Xu, H.; Sun, J.X. Changes in water use with growth in Ulmus pumila in semiarid sandy land of northern China. Trees 2013, 28, 41-52. [CrossRef]

5. Li, Y.G.; Jiang, G.M.; Liu, M.Z.; Niu, S.L.; Gao, L.M.; Cao, X.C. Photosynthetic response to precipitation/ rainfall in predominant tree (Ulmus pumila) seedlings in Hunshandak Sandland, China. Photosynthetica 2007, 45, 133-138. [CrossRef]

6. Jiang, D.M.; Liu, Z.M.; Cao, C.Y; Kou, Z.W.; Wang, R.Y. Desertification and Ecological Restoration of Keerqin Sandy Land; China Environmental Science Press: Beijing, China, 2003.

7. Liu, Z.M. Plant Regenerative Strategies; China Meteorological Press: Beijing, China, 2010.

8. Liu, Z.M.; Yan, Q.L.; Li, X.L.; Ma, J.L.; Ling, X. Seed mass and shape, germination and plant abundance in a desertified grassland in northeastern Inner Mongolia. J. Arid Environ. 2007, 69, 198-211. [CrossRef]

9. Maun, M.A. Seed-Germination and Seedling Establishment of Calamovilfa-Longifolia on Lake Huron Sand Dunes. Can. J. Bot. 1981, 59, 460-469. [CrossRef]

10. Maun, M.A. Adaptations of plants to burial in coastal sand dunes. Can.J. Bot. 1998, 76, 713-738.

11. Tang, J.; Jiang, D.M.; Wang, Y.C. A review on the process of seed-seedling regeneration of Ulmus pumila in sparse forest grassland. Chin.J. Ecol. 2014, 33, 1114-1120.

12. Dulamsuren, C.; Hauck, M.; Nyambayar, S.; Bader, M.; Osokhjargal, D.; Oyungerel, S.; Leuschner, C. Performance of Siberian elm (Ulmus pumila) on steppe slopes of the northern Mongolian mountain taiga: Drought Stress and Herbivory in Mature Trees. Environ. Exp. Bot. 2009, 66, 18-24. [CrossRef]

13. Ma, C.G. A Provenance Test of White Elm (Ulmus-Pumila L) in China. Silvae Genet. 1989, 38, 37-44.

14. Wesche, K.; Walther, D.; von Wehrden, H.; Hensen, I. Trees in the desert: Reproduction and Genetic Structure of Fragmented Ulmus pumila forests in Mongolian drylands. Flora-Morphol. Distrib. Funct. Ecol. 2011, 206, 91-99. [CrossRef]

15. Dong, M.; Alaten, B. Clonal plasticity in response to rhizome severing and heterogeneous resource supply in the rhizomatous grass Psammochloa villosa in an Inner Mongolian dune. China. Plant. Ecol. Plant. 1999, 141, 53-58. [CrossRef]

16. Shi, L.; Zhang, Z.J.; Zhang, C.Y.; Zhang, J.Z. Effects of sand burial on survival, growth, gas exchange and biomass allocation of Ulmus pumila seedlings in the Hunshandak Sandland. Ann. Bot. 2004, 94, 553-560. [CrossRef] [PubMed]

17. Liu, B.; Liu, Z.; Lü, X.T.; Maestre, F.T.; Wang, L.X. Sand burial compensates for the negative effects of erosion on the dune-building shrub Artemisia wudanica. Plant. Soil 2013, 374, 263-273. [CrossRef]

18. Jiang, D.M.; Tang, Y.; Busso, C.A. Effects of vegetation cover on recruitment of Ulmus pumila L. in Horqin Sandy Land. J. Arid Land. 2013, 6, 343-351. [CrossRef]

19. Dulamsuren, C.; Hauck, M.; Nyambayar, S.; Osokhjargal, D.; Leuschner, C. Establishment of Ulmus pumila seedlings on steppe slopes of the northern Mongolian mountain taiga. Acta Oecologica 2009, 35, 563-572. [CrossRef]

20. Tang, Y.; Jiang, D.M.; Lü, X.T. Effects of Exclosure Management on Elm (Ulmus pumila) Recruitment in Horqin Sandy Land. Arid Land Res. Manag. 2013, 28, 109-117. [CrossRef]

21. Aguirre, L.; Johnson, D.A. Root morphological development in relation to shoot growth in seedlings of four range grasses. J. Range Manag. 1991, 44, 341-346. [CrossRef]

22. Aguirre, L.; Johnson, D.A. Influence of temperature and cheatgrass competition on seedling development of two bunchgrasses. J. Range Manag. 1991, 44, 347-354. [CrossRef] 
23. Allen, M.F.; Hipps, L.E.; Woolridge, G.L. Wind dispersal and subsequent establishment of VA mycorrhizal fungi across a successional arid landscape. Landsc. Ecol. 1989, 2, 165-171. [CrossRef]

24. Brown, R.W. The water relation of range plants: Adaptions to Water Deficits. In Wildland Plants:Physiological Ecology and Developmental Morphology; Bedunahy, D.J., Sosebee, R.E., Eds.; Society for Range Management: Littleton, CO, USA, 1995; pp. 219-413.

25. Soriano, S.D.; Marti, V.P. Soil moisture determination at field capacity. In Edaphology and Climatology; Politenic University of Valencia: Alfaomega, Spain, 2004.

26. Rozema, J. The influemce of salinity, inundation and temperature on germination of some halophytes and non-halophytes. Oecol. Plant. 1975, 10, 341-353.

27. Sokal, R.R.; Rohlf, E.J. Biometry: The Principles and Practice of Statistics in Biological Research, 3rd ed.; W. H. Freeman: New York, NY, USA, 1995.

28. Zhu, Y.J.; Yang, X.J.; Baskin, C.C.; Baskin, J.M.; Dong, M.; Huang, Z.Y. Effects of amount and frequency of precipitation and sand burial on seed germination, seedling emergence and survival of the dune grass Leymus secalinus in semiarid. Plant. Soil. 2014, 374, 399-409. [CrossRef]

29. Nie, C.L.; Zheng, Y.R. Effects of water supply and sand burial on seed germination and seedling emergence of four dominant psammophytes in the ordos plateau. Acta Ecol. Sin. 2005, 29, 32-41.

30. Chang, W.; Wu, J.G.; Liu, Y.H. Research advance in seed germination of desert woody plants. Chin. J. Appl. Ecol. 2007, 18, 436-444.

31. Seiwa, K.; Watanabe, A.; Saitoh, T.; Kannu, H.; Akasaka, S. Effects of burying depth and seed size on seedling establishment of Japanese chestnuts, Castanea crenata. Forest Ecol. Manag. 2002, 164, 149-156. [CrossRef]

32. Liu, H.J.; Guo, K. The impacts of sand burial on seedling development of Caragana intermedia. Acta Ecol. Sin. 2005, 25, 2550-2555.

33. Baskin, C.C.; Baskin, J.M. Seeds Ecology, Biogeography and Evolution of Dormancy and Germination; Academic Press: San Diego, CA, USA, 1998.

34. Huang, Z.Y.; Gutterman, Y. Comparison of germination strategies of Artemisia ordosica with its two congeners from deserts of China and Israel. Acta Ecol. Sin. 2000, 42, 71-80.

35. Huang, Z.Y.; Gutterman, Y.; Osborne, D.J. Value of the mucilaginous pellicle to seeds of the sand-stabilizing desert woody shrub Artemisia sphaerocephala (Asteraceae). Trees-Struct Funct. 2004, 18, 669-676. [CrossRef]

36. Liu, G.J.; Zhang, X.M.; Li, J.G.; Fan, D.D.; Deng, C.Z.; Hou, J.G.; Xin, R.M. Effects of Water Supply and Sand Burial on Seed Germination and Seedling Emergence of Haloxylon Ammodendronand Haloxylon Persicum. J. Desert Res. 2010, 30, 1085-1091.

37. Huang, Z.Y.; Gutterman, Y. Artemisia monosperma achene germination in sand: Effects of Sand Depth, Sand/Water Content, Cyanobacterial Sand Crust and Temperature. J. Arid Environ. 1998, 38, 27-43. [CrossRef]

38. Cheplick, G.P.; Grandstaff, K. Effects of sand burial on purple sandgrass (Triplasis purpurea): The Significance of Seed Heteromorphism. Plant Ecol. 1997, 133, 79-89. [CrossRef]

39. Sun, Z.G.; Mou, X.J.; Lin, G.H.; Wang, L.L.; Song, H.Q.; Jiang, H.H. Effects of sediment burial disturbance on seedling survival and growth of Suaeda salsa in the tidal wetland of the Yellow River estuary. Plant. Soil. 2010, 337, 457-468. [CrossRef]

40. Zhu, Y.; Dong, M.; Huang, Z.Y. Effects of sand burial and seed size on seed germination and seedling emergence of Psammochola villosa. Acta Ecol. Sin. 2005, 29, 730-739.

41. Wang, J.H.; Chai, Y.F.; Zhang, Y. Effects of sand burial depth of Achnatherum inebrians seed on its germination and seedling growth. Chin. J. Ecol. 2010, 29, 324-328.

42. Yang, H.L.; Cao, Z.P.; Dong, M.; Ye, Y.Z.; Huang, Z.Y. Effects of sand burying on caryopsis germination and seedling growth of Bromus inermis Leyss. Chin. J. Appl Ecol. 2007, 18, 2438-2443.

(C) 2016 by the authors; licensee MDPI, Basel, Switzerland. This article is an open access article distributed under the terms and conditions of the Creative Commons by Attribution (CC-BY) license (http:/ / creativecommons.org/licenses/by/4.0/). 